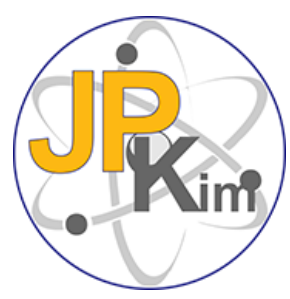

Jurnal Pendidikan Kimia

Vol. 13 | No. 1 |1 - 9| April | 2021

ISSN: 2085-3653| e-ISSN: 2549-3116

https://jurnal.unimed.ac.id/2012/index.php/jpk

https://jurnal.unimed.ac.id

\title{
Synthesis and characterization of capsule shells non gelatin grass jelly leaves-seaweed as drug delivery system material
}

\author{
Micha Mahardika, ,*, Fauzan Amin', Ika Agustia Umami1, Boima \\ Situmeang ${ }^{1}$, and Agus Malik Ibrahim ${ }^{1}$ \\ 'Department of Chemistry, Sekolah Tinggi Analis Kimia Cilegon, Cilegon, Banten, Indonesia \\ *Corresponding author: MM, micha.mahardika@gmail.com
}

DOI: $10.24114 / j p k i m . v 13 i 1.24138$

Article history:

Received: 23 November 2020

Revised: 15 March 2021

Accepted: 18 March 2021

\begin{abstract}
Drug delivery system is a system that describes the journey of a drug to its target location. The main component of the drug delivery system is gelatin. The leaves of grass jelly-seaweed are needed as a raw material for gelatin. The main component of gelling agents in grass jelly leaves and seaweed is a low-methoxy pectin polysaccharide. Pectin from previous study is used as a synthesis material for hard capsule shells with the addition of other ingredients, which are Na-CMC, sorbitol, and water. The characterization results of capsule shells with variations in the composition of grass jelly-seaweed leaves $0: 4,1: 3,2: 2,3: 1$, and $4: 0$ ( $A, B, C, D$ and $E$ ) have a disolving time of 12 minutes 45 seconds; 15 minutes 53 seconds; 23 minutes 10 seconds; 15 minutes 35 seconds and 18 minutes 12 seconds. The swelling degree test each of $200 \%$; $266,7 \%$; $303.3 \%$; $586.7 \%$ and $643.3 \%$. Furthermore, the shells of grass jelly-seaweed leaf capsules were tested for their material performance in the cefadroxyl disolving test with variations in sampling time of 10, 20, and 30 minutes.
\end{abstract}

Keywords: Cefadroxyl, Drug delivery system, Green grass jelly leaves, Non-gelatin capsules, Seaweed

\section{Introduction}

Capsules as a drug delivery system in the pharmaceutical world have been widely used for a long time. Several types of drug delivery methods include oral, parenteral, local, rectal, transdermal and inhalation. The oral method is the most popular method in society because it is an easy, safe and simple (Shargel et al. 2007).

Gelatin has high hydrophilic that can be seen from its function as stabilizer, gelling agent, binders, emulsifiers, and thickeners (Raja et al. 2017). The largest production of gelatin in the world came from raw pork skin $44.5 \%$ (136,000 tons), second from cowhide $27.6 \%$ ( 84,000 tons), third from bone $26.6 \%$ (81,000 tonnes) and the rest 
comes from other than 1.3\% (4,000 tonnes) (Harianto et al. 2008). Based on the data, capsules made from vegetable are needed so that they can be used for Muslims, Jews, Hindus, and vegetarians who cannot consume gelatin capsules, the largest percentage of which uses pork kilit as raw material.

Hidayana et al. (2018), has conducted research on the manufacture of pectinbased capsule shells by utilizing aloe vera pectin flour as an alternative material for making hard capsule shells. It was concluded from several optimizations for the capsule shell production formula, the pectin concentration was $1 \%$; $\mathrm{CMC} 8.5 \%$; $\mathrm{CaCl} 2$ $0.03 \%$; Aquadest $90.47 \%$ tends to have better characteristics, but the specifications of the capsule shell made from aloe pectin flour are not the same as the capsule shell made from gelatin so that some optimization is still needed to produce capsule shells with good quality. Aloe vera known as a multi function plant that contain tanins, saponin and flavonoid (Lestari et al. 2015; Harefa \& Silaban, 2020).

Grass jelly leaves are needed as an alternative to the raw material for gelatin. Grass jelly plants are native to Indonesia and have other names including Camcao, Juju, Kepleng (Java); Camcauh, Formerly (Sundanese). The main component of green grass jelly extract that forms a gel is a low-methoxy pectin polysaccharide. Apart from grass jelly leaves, carrageenan is also another ingredient that is used as a substitute for gelatin. Carrageenan is a hydrocolloid compound derived from Rhodophyceae seaweed, the type of seaweed used is Gracilaria sp. The availability of abundant raw materials and guaranteed halalness is expected to replace gelatin capsules as commercial capsules so that all people can consume them. Plant based synthesis is more advantages due to their its therapeutic potency as bactericidal, fungicidal, nematicidal, mosquitocidal and anticancer agent (Amin et al. 2019).

\section{Methods}

\subsection{Materials/Sample and Population}

Materials used in synthesis of capsule shells non gelatin grass jelly leaves-seawed are a blender, oven, furnace, desiccator, analytical balance, a set of titration tools, hot plate, UV-Vis spectrophotometer, erlenmeyer, baking sheet, modified dissolution equipment, modified disintegration time test equipment, ethanol, $\mathrm{NaCl}$, aquadest, $\mathrm{pp}$ indicator, 0.1 and $0.25 \mathrm{~N} \mathrm{NaOH}, 0.25 \mathrm{~N} \mathrm{HCl}$, sorbitol, $\mathrm{Na}-\mathrm{CMC}$, cefadroxil monohydrate, and sollution buffer.

\subsection{Synthesis of capsule shells non gelatin}

Synthesis of capsule shells non gelation using formulation on the Table 1 with variations of grass jelly and seaweed extract.

\subsection{Characterization of Capsule Shell Capsule Shell Weight}


Weighed 3 capsule shells and then calculated the average shell weight capsules, standard deviation, and relative standard deviation.

Dissolve Time Test

The capsules were put into the disintegration time tester containing aquadest at $37^{\circ} \mathrm{C}$. then the disintegration time tester containing the sample is watered lower it until the capsule shell is crushed. Then note the time it takes capsule to crush.

Swelling Degree Test

Capsule shells are weighed and their weight recorded. Capsule shell soaked in 70 $\mathrm{ml}$ aquadest for 1 hour. The capsules that have absorbed water are separated from the water solvent by filter paper. Then reweighed to determine the final capsule weight.

\subsection{Capsule Material Performance Dissolution Test}

Capsules are filled with $500 \mathrm{mg}$ of Cefadroxyl monohydrate. Then put in a modified glass beaker containing $25 \mathrm{~mL}$ of buffer solution with a $\mathrm{pH}$ of 2 . Stir at a speed of $100 \mathrm{rpm}$ in variations of time 10, 20, and 30 minutes. $10 \mathrm{~mL}$ of the solution were taken and then tested using a spectrophotometer UV-Vis at a wavelength of $320 \mathrm{~nm}$.

Table 1

Variations of capsule shell formulation

\begin{tabular}{c|c|c|c|c}
\hline $\begin{array}{c}\text { Grass jelly leaves extract } \\
(\%)\end{array}$ & $\begin{array}{c}\text { Seawed extract } \\
(\%)\end{array}$ & $\begin{array}{c}\text { Sorbitol } \\
(\%)\end{array}$ & $\begin{array}{c}\text { Na-CMC } \\
(\%)\end{array}$ & $\begin{array}{c}\text { Aquadest } \\
(\%)\end{array}$ \\
\hline 0 & 4 & 1 & 2 & 93 \\
\hline 1 & 3 & 1 & 2 & 93 \\
\hline 2 & 2 & 1 & 2 & 93 \\
\hline 3 & 1 & 1 & 2 & 93 \\
\hline 4 & 0 & 1 & 2 & 93 \\
\hline
\end{tabular}

\section{Results and Discussion}

The main ingredients used in this study were green grass jelly leaves (Premna oblongifolia merr) and seaweed (Gracilaria $s p$ ). These two materials were chosen because of their availability which is easily found in the surrounding environment. Green grass jelly (Premna oblongifolia merr) is one of the high fiber food plants. The fiber content in grass jelly is hydrocolloid or water soluble so it can form a gel.

\subsection{Capsule Production}

Variations in the pectin composition of grass jelly leaves, seaweed, $\mathrm{Na}-\mathrm{CMC}$ and sorbitol were carried out in order to obtain optimum capsule characteristics. In the 
manufacturing, the characteristics of the capsules are strongly influenced by the preparation technique, including: stirring, temperature regulation, and material homogeneity and printing (Fauzi, 2016). Fig 1 below shows the process of forming the capsule shell of grass jelly leaves-seaweed.

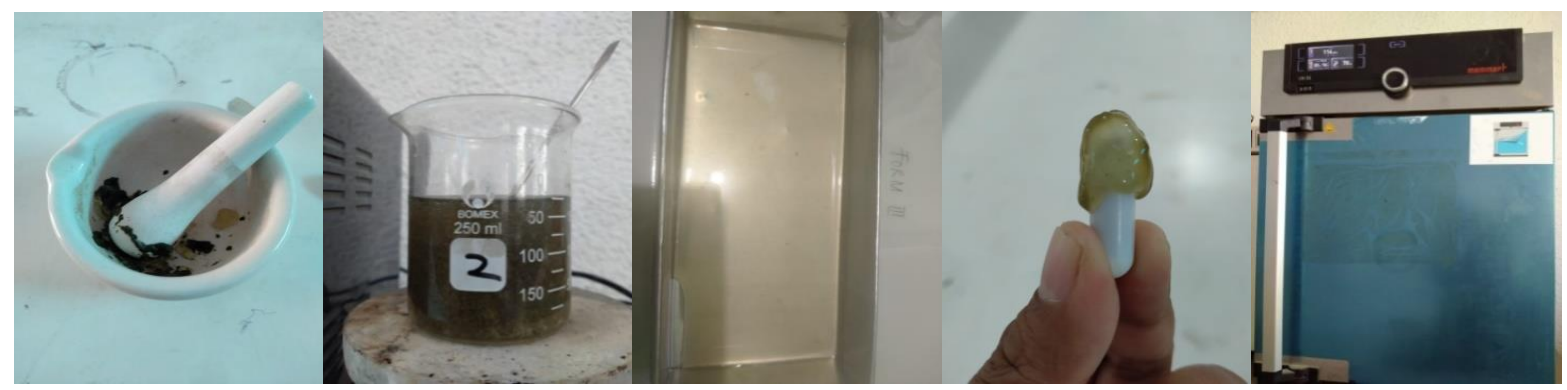

Fig 1. The process of making grass jelly leaves-seaweed capsule shells

Based on the picture above, the grass jelly leaves pectin with certain variations in composition is mashed first. The mixture of grass jelly leaves pectin and $\mathrm{Na}-\mathrm{CMC}$ in a beaker is added aquadest gradually to form a colloidal solution. The presence of sorbitol as a plasticizer causes the mixture that was originally thick to become softer. This is supported by the large number of $-\mathrm{OH}$ groups in sorbitol which increase the mixed hydrogen bonding to the water solvent.

The mixture is continuously stirred for ten minutes at room temperature or until the solution is turning homogeneous and completely mixed. The homogeneous mixture is poured into a container or baking sheet and then leave at room temperature for 12 hours so that the sample is not too liquid when printed. Then the samples were printed using a spin bar and then dried in an oven at $100^{\circ} \mathrm{C}$.

The grass jelly leaf pectin with certain composition variations is mashed first so that it does not form clumps when sorbitol and Na-CMC are added. The heat needs to be maintained, if there is a decrease in temperature during heating, the gel will harden. Meanwhile, if there is an increase in excess temperature, the gel will melt easier so it is difficult to print. The capsule shells were made with different variations in the composition of grass jelly leaves and seaweed, namely $0: 4,1: 3,2: 2,3: 1$, and 4: 0 which were coded with the capsule formulas A, B, C, D, and E. Table 2 below shows the results of making grass jelly leaves-seaweed capsule shells.

The table below shows that giving variations in the composition of the capsule shell affects the physical feature of the capsule shell. The softest capsule shell is produced from the shell of capsule $A$, while the hardest and toughest capsule shell is produced from the capsule shell $C$. The capsule shell is made weighing of $300 \mathrm{mg}$ with the different variations in the composition of grass jelly leaves and seaweed. Then the capsule shell is filled with the active ingredient of the drug Cefadroxyl Monohydrate to be tested for its material characteristics and performance. 
Table 2

Results of making grass jelly-seaweed leaf capsule shells

\begin{tabular}{c|c|l|l}
\hline NO & Capsule & \multicolumn{1}{|c}{ Observation Result } & Picture \\
\hline 1 & A & $\begin{array}{l}\text {-The capsule shell is } \\
\text { brownish white. } \\
\text {-Soft }\end{array}$ & \\
\hline 3 & B & $\begin{array}{l}\text {-The capsule shell is green } \\
- \text { Hard and sturdy }\end{array}$ & \\
\hline 4 & D & $\begin{array}{l}\text {-The capsule shell is green }++ \\
\text {-Hard and sturdy ++ }\end{array}$ & \\
\hline 5 & E & $\begin{array}{l}\text {-The capsule shell is dark } \\
\text {-Stiff and soft }\end{array}$ & \\
\hline & $\begin{array}{l}\text { green }++ \\
\text {-Stiff and soft ++ }\end{array}$ & \\
\hline
\end{tabular}

\subsection{Capsule Shell Weight}

The results of measuring the weight of capsules A, B, C, D, and E are presented in Table 3. Based on the data below, the average weight of capsule shells on capsule shell $A$ is $302.2 \mathrm{mg}$, capsule shell $B$ is $305.3 \mathrm{mg}$, capsule shell $C$ is $306.1 \mathrm{mg}$, capsule shell $D$ is $302.5 \mathrm{mg}$, and capsule $\mathrm{E}$ shell is $310.7 \mathrm{mg}$. From these data, the capsule shells of grass jelly leaves-seaweed have a good weight diversity. This can be seen from the relative standard deviation (RSD), which is $<2 \%$.

Table 3

Measurement of capsule shell weights A, B, C, D, and E

\begin{tabular}{c|c|c|c|c|c}
\hline \multirow{2}{*}{ Repetition } & \multicolumn{5}{|c}{ Capsule Shell (mg) } \\
\cline { 2 - 6 } & A & B & C & D & E \\
\hline I & 303.8 & 309.3 & 310.7 & 300.7 & 312.8 \\
\hline II & 302.5 & 300.4 & 302.3 & 301.6 & 307.5 \\
\hline III & 300.2 & 306.3 & 305.2 & 30.3 & 311.9 \\
\hline Average & 302.2 & 305.3 & 306.1 & 302.5 & 310.7 \\
\hline SD & 1.8 & 4.5 & 4.3 & 2.4 & 2.8 \\
\hline RSD & 0.6 & 1.5 & 1.4 & 0.8 & 0.9 \\
\hline
\end{tabular}




\subsection{Dissolve Time Test}

According to the 5th edition of the Indonesian Pharmacopoeia, the specification requirement for the capsule dissolving test time is no more than 30 minutes. The results test of the grass jelly leaves-seaweed capsule shells dissolving time are presented in Table 4.

Table 4

The results of the capsule shell dissolving time test

\begin{tabular}{c|c}
\hline Capsule Shell & Dissolving Time \\
\hline A & 12 minutes 45 seconds \\
\hline B & 15 minutes 53 seconds \\
\hline C & 23 minutes 10 seconds \\
\hline D & 15 minutes 35 seconds \\
\hline E & 18 minutes 12 seconds \\
\hline
\end{tabular}

Based on the data above, it can be concluded that the capsule shells A, B, C, D, and $\mathrm{E}$ meet the requirements of the $\mathrm{V}$ edition of the Indonesian Pharmacopoeia specification, which is no more than 30 minutes. The factors affecting the disolving time are the different weight and thickness of the capsule shell. This is due to the difficulty in the process of forming the capsule shell.

\subsection{Swelling Degree Test}

Swelling degree test's aim is to determine the ability of the capsule shell to absorb water. The greater the swelling value, the faster the drug release time. Fig 2 below shows the process of testing the swelling content of a grass jelly leaves-seaweed capsule shell. The swelling degree analysis of the capsule shell is carried out by immersing the sample in $100 \mathrm{~mL}$ of aquadest for 1 hour. The sample which has absorbed water is separated from the water solvent and then weighed to determine its mass. This water absorption does not break the pectin and Na-CMC chains directly because of swelling degree that prevents the breakdown. The test results of the swelling degree of capsule shells A, B, C, D, and E can be seen in Table 5.

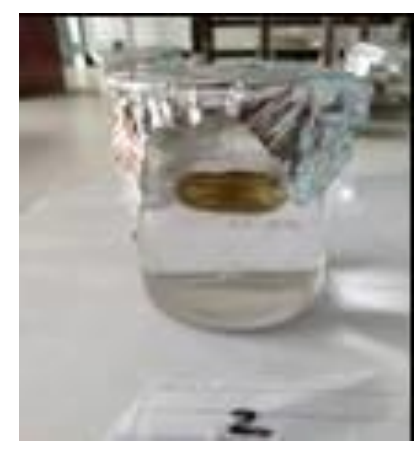

Fig 2. The test process for swelling of grass jelly leaves-seaweed capsule shells 
Based on the Table 5, the order of the capsule shell swelling degree is $A<B<C<D$ $<E$. One of the factors that affected the swelling degree is the number of cavities between the polymer bonds. It can be concluded that $\mathrm{E}$ capsule is the best capsule based on the swelling degree because it has the largest swelling degree. However, it does not stop the possibility for other capsule formulations to be used in drug delivery system applications based on the needs.

Table 5

The test results of the swelling degree of the capsule shell

\begin{tabular}{c|c|c|c}
\hline Capsule Shell & $\mathrm{W}_{\mathrm{o}}$ (gram) & $\mathrm{W}_{\mathrm{t}}$ (gram) & $\mathrm{Q}(\%)$ \\
\hline A & 0.3 & 0.9 & 200 \\
\hline B & 0.3 & 1.1 & 266.7 \\
\hline C & 0.3 & 1.21 & 303.3 \\
\hline D & 0.3 & 2.06 & 586.7 \\
\hline E & 0.3 & 2.23 & 643.3 \\
\hline
\end{tabular}

Information: $\mathrm{Q}=$ swelling degree; $\mathrm{Wt}=$ mass of the capsule that has absorbed water; $\mathrm{Wo}_{\mathrm{O}}=$ mass of capsule before absorbing water

\subsection{Capsule Material Performance}

Dissolution Test. The dissolution test's aim is to determine the solubility of active substances from medicinal preparations in the body for absorption (Karimah, 2016). The dissolution test done for the capsule form evacuation is different from conventional preparations, both in terms of equipment and the duration of the dissolution process. One very good dissolution method as published by Gohel et al. (2014). In this dissolution test, a modified beaker was used by adding a sampling channel attached to the bottom of the beaker. The medium used is adjusted to the conditions in the stomach, both $\mathrm{pH}$, amount of fluid and gastric motility rate. The dissolution test process can be seen in Fig 3 .

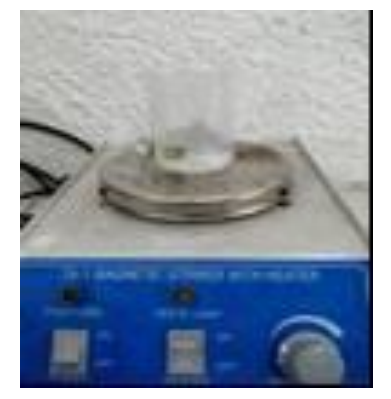

Fig 3. The dissolution test process

Based on the Fig 3, the capsule shell that has been filled with $300 \mathrm{mg}$ of cefadroxyl monohydrate is put into a modified glass beaker filled with $25 \mathrm{~mL} \mathrm{of} \mathrm{pH} 2$ buffer liquid then stirred (adjusting the stomach $\mathrm{pH}$ ). Stirring was done at a speed of 100 rpm (Pharmacope Indonesia ed. V, 2014) in variations of 10, 20, and 30 minutes. 
The cefadroxil concentration was measured using a Uv-Vis spectrovotometer at a wavelength of $320 \mathrm{~nm}$. The results of the distribution of cefadroxyl solute substance in grass jelly leaves capsule shells can be seen in Table 6 .

Table 6

Distribution table of cefadroxyl monohydrate solutes

\begin{tabular}{c|c|c|c|c|c|c}
\hline \multirow{2}{*}{ Sampling Time } & \multicolumn{5}{|c|}{ Capsule shell formulation } & \multirow{2}{*}{ Total } \\
\cline { 2 - 6 } & $\mathrm{A}$ & $\mathrm{B}$ & $\mathrm{C}$ & $\mathrm{D}$ & $\mathrm{E}$ & \\
\hline 10 minutes & 0.037 & 0.042 & 0.015 & 0.059 & 0.014 & \\
\hline 20 minutes & 0.046 & 0.068 & 0.019 & 0.062 & 0.019 & \\
\hline 30 minutes & 0.073 & 0.095 & 0.03 & 0.067 & 0.025 & \\
\hline Total & 0.156 & 0.205 & 0.064 & 0.188 & 0.058 & 0.671 \\
\hline $\begin{array}{c}\text { Observation } \\
\text { amount }\end{array}$ & 3 & 3 & 3 & 3 & 3 & 15 \\
\hline Average & 0.052 & 0.068 & 0.021 & 0.063 & 0.019 & 0.224 \\
\hline
\end{tabular}

\section{Conclusion}

Synthesis of capsule shells non gelatin from grass jelly leaves-seaweed has been succced. Based on characterization results of grass jelly-seaweed leaf capsule shells with ratio of $0: 4,1: 3,2: 2,3: 1$, and 4:0 obtained the results of the swelling test on Capsule shell number $\mathrm{D}$ is $643.3 \%$.

\section{Acknowledgment}

We thank Ristekdikti as a funding source of this research and Sekolah Tinggi Analis Kimia Cilegon for the place to us to conduct research.

\section{References}

Amin, F., Mahardika, M., \& Morisca, N. (2019). Synthesis and characterization of gold nanoparticles using fruit extract of Crescentia cujete L. Jurnal Pendidikan Kimia, 11(3), 9599. DOI: 10.24114/jpkim.v11i3.15737

Fauzi, M.A. 2016. Kopolimer alginat-karagenan dengan adisi plasticizer sorbitol sebagai material drug delivery carrier. Thesis. Fakultas Sains dan Teknologi. Universitas Airlangga. Surabaya

Gohel, M. C., Mehta, P. R., Dave, R. K., \& Bariya, N. H. (2004). A More Relevant Dissolution Method for Evaluation of Floating Drug Delivery System. Dissolution Technologies, 11(4), 22-25. DOI: $10.14227 / \mathrm{dt} 110404 \mathrm{p} 22$

Harefa, N., \& Silaban, S. (2020). Identification of metal content in food using gravimetric and iodometric methods: The case on children's food. Jurnal Pendidikan Kimia, 12(2), 5261. DOI: $10.24114 / j p k i m . v 12 i 2.19395$ 
Harianto, H., Tazwir, T., \& Peranginangin, R. (2008). Studi teknik pengeringan gelatin ikan dengan alat pengering kabinet. Jurnal Pascapanen Dan Bioteknologi Kelautan dan Perikanan, 3(1), 89. DOI: 10.15578/jpbkp.v3i1.13

Hidayana, D. A., Herawati, E. D., \& Aprilia, W. H. (2018). Karakterisasi dan pembuatan cangkang kapsul dari tepung pektin lidah buaya [Aloe vera (L.) Burm. f] sebagai alternatif bahan pembuatan cangkang kapsul keras. Institut Pertanian Bogor, Bogor.

Karimah, M. (2016). Pembuatan dan karakterisasi kapsul pati-alginat dari ekstraksi rumput laut coklat (Sargassum sp.) sebagai material drug delivery system. Skripsi. Universitas Airlangga.

Kementrian Kesehatan Republik Indonesia. (2014). Farmakope Indonesia Edisi V. Jakarta.

Lestari, M., Nasution, M. P., \& Suryani, S. (2015). Potensi ekstrak etanol daun lidah buaya (Aloe vera L.) sebagai antifertilitas melalui tampilan imunohistokimia caspase 3 aktif pada testis serta penilaian kuantitas dan kualitas spermatozoa mencit (Mus musculus L.). Jurnal Pendidikan Kimia, 7(2), 21-30.

Raja, P. M, \& Nurfajriani, N. (2017). Pembuatan adsorben dari kitosan cangkang belangkas (Tachypleus gigas) dan gelatin untuk menurunkan kadar logam timbal $(\mathrm{Pb})$. Jurnal Pendidikan Kimia, 9(1), 282-285. DOI: 10.24114/jpkim.vgi1.6203

Shargel, L., Wu-Pong, S., \& Yu, A. B. (2007). Applied biopharmaceutics \& pharmacokinetics. Mcgraw-hill. 